\title{
An unusual cause of proptosis
}

\author{
Arjun Gupta, ${ }^{1}$ Zehra Farzal, ${ }^{1}$ Ambarish Pandey ${ }^{2}$
}

${ }^{1}$ UT Southwestern Medical Center, Dallas, Texas, USA ${ }^{2}$ Department of Internal Medicine, University of Texas Southwestern Medical Center, Dallas, Texas, USA

\section{Correspondence to}

Dr Ambarish Pandey, ambarish.pandey@outlook.com

Accepted 28 July 2015

\section{CrossMark}

$$
\begin{aligned}
& \hline \text { To cite: Gupta A, Farzal Z, } \\
& \text { Pandey A. BMJ Case Rep } \\
& \text { Published online: [please } \\
& \text { include Day Month Year] } \\
& \text { doi:10.1136/bcr-2015- } \\
& 211741 \\
& \hline
\end{aligned}
$$

\section{DESCRIPTION}

A 20-year-old woman presented with gradually progressive proptosis and inability to completely close her eyes. She reported no trauma, sinusitis or history of thyroid disease. Examination revealed bilateral painless cervical lymphadenopathy and proptosis. Eye abduction was limited; the rest of the extraocular movements were intact. Haemogram and thyroid function tests were in the normal range. MRI of the brain demonstrated bilateral bulky intraconal masses with stretching of the optic nerve and effacement of the extraocular muscles (figure 1). Lymph node biopsy revealed pericapsular fibrosis and infiltration of large cells staining positive for S-100 and CD68, characteristic of a histiocyte disorder. CD1a was negative. No evidence of bone disease was identified. A diagnosis of Rosai-Dorfman disease (RDD) was made, and single-agent clofarabine initiated. The course was complicated by neutropenic fevers, shingles and nausea. MRI showed stable disease in the orbits (figure 2) but complete resolution of cervical lymphadenopathy clinically, and on extension of MRI, down to the neck.

RDD is a rare benign histiocytic disorder of uncertain aetiology, seen in young adults. Patients usually present with bulky lymphadenopathy. Extranodal sites of involvement include skin, soft tissue, bone, upper airways and retro-orbital tissue. Patients may present with proptosis secondary to orbital disease, as in our patient. ${ }^{1}$ Causes of

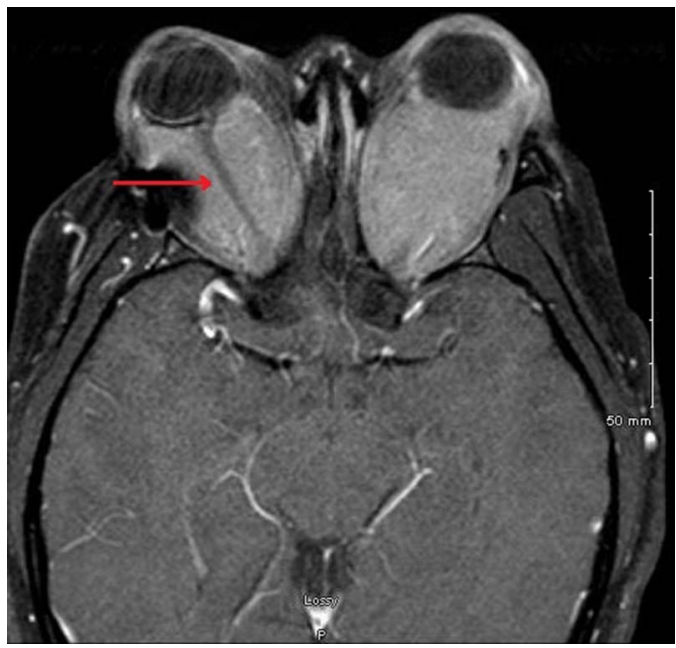

Figure $1 \mathrm{MRI}$ of the brain (T1 postgadolinium) showing bilateral bulky intraconal masses with homogeneous contrast enhancement. The masses are causing effacement of the extraocular muscles and significant proptosis with stretching of the optic nerve (red arrow). There is no tenting of the globe, suggestive of a chronic phenomenon. The intraocular contents appear grossly normal.

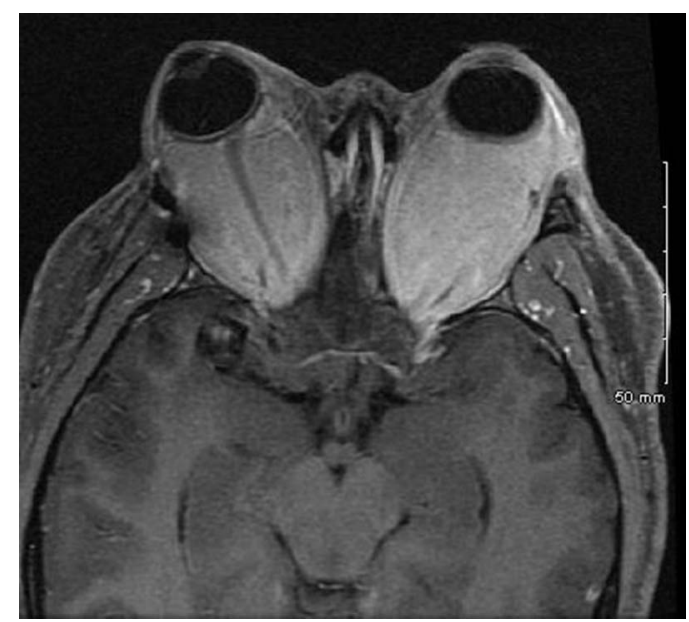

Figure $2 \mathrm{MRI}$ of the brain showing stable intraorbital disease.

proptosis include trauma, infection (cellulitis), thyroid disease, vascular lesions and neoplasms (meningioma). In our case, sarcoidosis and lymphoma were considered given the additional cervical lymphadenopathy. Infectious aetiologies were also considered; proptosis can occur with sinusitis, orbital cellulitis and meningitis, but the patient had a subacute presentation and was not acutely ill. Rare fungal and slow-growing atypical organisms can cause eye infection and proptosis but are usually accompanied by 'B' symptoms and a more acute course. Gradual progressive proptosis is suggestive of a benign growth, such as RDD. Pathology is diagnostic with characteristic 'emperipolesis', where lymphocytes reside in the cytoplasm of the histiocytes, and negative CD1a, differentiating it from Langerhans cell histiocytosis. Treatment strategies are variable, including surgical resection, radiation and chemotherapy, depending on disease site and extent. ${ }^{2}$ Clofarabine has been especially effective in bone and orbital disease, and is currently being received by our patient. ${ }^{3}$ Orbitotomy can be considered for these patients depending on their clinical response.

\section{Learning points}

- Gradually progressive bilateral proptosis may be a presenting sign of orbital neoplastic disease such as Rosai-Dorfman disease (RDD).

- RDD is a rare benign histiocytic disorder characterised by nodal and extranodal histiocyte proliferation.

- Clofarabine has emerged as an effective agent for bone and orbital disease. 
Competing interests None declared.

\section{Patient consent Obtained.}

Provenance and peer review Not commissioned; externally peer reviewed.

\section{REFERENCES}

1 Rodrigues AC, Medeiros-Neto G. Inflammatory proptosis in Rosai-Dorfman disease simulating thyroid-associated ophthalmopathy. Thyroid 2009;19:801-2.
2 Sanli A, Eken M, Oktay ZA, et al. Rosai-Dorfman disease: sinus histiocytosis with massive lymphadenopathy. BMJ Case Rep 2009;2009:pii: bcr11.2008.1251.

3 Simko SJ, Tran HD, Jones J, et al. Clofarabine salvage therapy in refractory multifocal histiocytic disorders, including Langerhans cell histiocytosis, juvenile xanthogranuloma and Rosai-Dorfman disease. Pediatr Blood Cancer 2014;61:479-87.

Copyright 2015 BMJ Publishing Group. All rights reserved. For permission to reuse any of this content visit http://group.bmj.com/group/rights-licensing/permissions.

BMJ Case Report Fellows may re-use this article for personal use and teaching without any further permission.

Become a Fellow of BMJ Case Reports today and you can:

- Submit as many cases as you like

- Enjoy fast sympathetic peer review and rapid publication of accepted articles

- Access all the published articles

- Re-use any of the published material for personal use and teaching without further permission

For information on Institutional Fellowships contact consortiasales@bmjgroup.com

Visit casereports.bmj.com for more articles like this and to become a Fellow 